\title{
GAMBARAN KESEHATAN JIWA MASYARAKAT
}

\author{
Livana PH $^{1}$, Sih Ayuwatini' ${ }^{2}$ Yulia Ardiyanti ${ }^{3}$, Ulfa Suryani ${ }^{4}$ \\ ${ }^{1}$ Program Studi Ners, STIKES Kendal \\ ${ }^{2}$ RSUD Dr. H. Soewondo Kendal \\ ${ }^{3}$ Program studi D3 Keperawatan, STIKES Muhammadiyah Kendal \\ ${ }^{4}$ Program studi ilmu keperawatan, STIKES Mercubaktijaya Padang \\ livana.ph@gmail.com
}

\begin{abstract}
ABSTRAK
Kesehatan jiwa tidak lagi hanya membahas tentang masalah gangguan jiwa saja, namun kelompok sehat dan resiko juga perlu diketahui agar masyarakat mendapatkan tindakan yang tepat yaitu, kelompok sehat agar tetap sehat; kelompok resiko tidak menjadi gangguan; dan kelompok gangguan tetap produktif di masyarakat, sehingga perlunya identifikasi masalah kesehatan jiwa masyarakat desa Banyutowo malalui deteksi dini. Penelitian bertujuan khusus: (1)Mengidentifikasi karakteristik masyarakat, meliputi:usia, jenis kelamin, pendidikan, dan status pernikahan, (2)Mengidentifikasi kelompok sehat, resiko, dan gangguan, (3)Publikasi ilmiah pada jurnal nasional sebagai luaran wajib. Data dianalisis dengan menghitung Central Tendency dan distribusi frekuensi. Hasil penelitian menunjukkan mayoritas masyarakat desa Banyutowo berusia dewasa, berjenis kelamin laki-laki, belum menikah, dan pendidikan terakhir SD. Hasil identifikasi kesehatan jiwa didapatkan bahwa mayoritas masyarakat desa Banyutowo dalam kelompok usia sehat. Hasil penelitian ini selanjutnya dapat ditindaklanjuti dengan memberikan intervensin pada masing-masing kelompok kesehatan jiwa, sehingga diharapkan dapat meningkatkan pengetahuan masyarakat tentang pentingnya kesehatan jiwa, meningkatkan kemampuan masyarakat menolong dirinya dalam bidang kesehatan jiwa, meningkatkan kesiapsiagaan masyarakat risiko dan bahaya kesehatan jiwa, dan meningkatkan dukungan dan peran aktif stakeholders serta meningkatkan masyarakat melaksanakan perilaku sehat jiwa.
\end{abstract}

Kata kunci: Kesehatan jiwa, masyarakat

\section{OVERVIEW OF COMMUNITY MENTAL HEALTH}

\begin{abstract}
Mental health is no longer just talking about mental disorders, but healthy groups and risks also need to be known so that people get the right action, namely, healthy groups to stay healthy; risk groups do not become a nuisance; and the disorder group remained productive in the community, so the need to identify Banyutowo village mental health problems through early detection. Special purpose research: (1) Identifying community characteristics, including: age, sex, education, and marital status, (2) Identifying healthy groups, risks, and disorders, (3) Scientific publications in national journals as mandatory outcomes. Data were analyzed by calculating Central Tendency and frequency distribution. The results showed that the majority of Banyutowo villagers were adults, male, unmarried, and final education in elementary school. The results of mental health identification found that the majority of the people in the Banyutowo village were in the healthy age group. The results of this study can then be followed up by giving intervensin to each mental health group, so that it is expected to increase public knowledge about the importance of mental health, improve community capacity to help themselves in the field of mental health, improve community preparedness of mental health risks and hazards, and increase support and the active role of stakeholders as well as improving the community to implement healthy mental behavior.
\end{abstract}

Keywords: mental health, society

\section{PENDAHULUAN}

Secara analogi menurut Hidayat (2002), kesehatan jiwa bukan hanya tidak adanya gangguan jiwa, melainkan mengandung berbagai karakteristik positif yang menggambarkan keselarasan dan keseimbangan jiwa yang mencerminkan kedewasaan dari kepribadian yang bersangkutan. Pelayanan kesehatan jiwa dimulai dari masyarakat dalam bentuk pelayanan kemandirian individu dan 
keluarganya, pelayanan kotoh masayrakat formal dan non formal di luar sektor kesehatan, pelayanan puskesmas, pelayanan di tingkat kabupaten/kota. Pelayanan kesehatan jiwa di Rumah Sakit dimulai dari pelayanan akut pada rumah sakit umum dan pelayanan spesialistik di Rumah Sakit Jiwa (CMHN, 2006)

Kementerian Kesehatan RI berupaya untuk memfasilitasi percepatan pencapaian derajat kesehatan setinggi-tingginya bagi seluruh penduduk dengan mengembangkan kesiapsiagaan di tingkat desa. Desa-desa yang memiliki kesiapan di bidang kesehatan disebut Desa Siaga. Desa siaga merupakan gambaran masyarakat yang sadar, mau dan mampu untuk mencegah dan mengatasi berbagai ancaman terhadap kesehatan masyarakat, seperti kurang gizi, kejadian bencana, termasuk gangguan jiwa dengan memanfaakan potensi masyarakat setempat secara gotong royong untuk menuju Desa Siaga Sehat Jiwa.

Sejak Tahun 2002, paradigma kesehatan Indonesia berfokus pada peningkatan dan pencegahan penyakit dengan memberdayakan potensi yang ada dimasyarakat secara optimal agar masyarakat lebih mandiri dalam menjaga kesehatannya. Salah satu bentuk pemberdayaan masyarakat yang diaktifkan adalah membentuk dan melatih kader kesehatan agar mempunyai kemampuan tertentu, salah satunya yaitu kemampuan sebagai Kader Kesehatan Jiwa (Kader Keswa). Diperkirakan satu tahun setelah terjadinya bencana di propinsi NAD dan Sumatera Utara timbul berbagai masalah psikososial dan gangguan jiwa. Hasil penelitian pada klien dengan masalah psikososial yang cepat dirawat dapat sembuh $25 \%$, mandiri $25 \%$, dan klien yang membutuhkan bantuan $25 \%$. Sedangkan klien yang mengalami gangguan jiwa berat dan butuh perawatan penuh $25 \%$. klien gangguan jiwa ini yang telah dirawat oleh perawat Community Mental Health Nursing $(\mathrm{CMHN})$ menunjukkan perbaikan dan $\pm 45 \%$ telah mandiri.

Berdasarkan hasil penelitian tersebut maka perlunya deteksi dini terkait kesehatan jiwa di masyarakat agar masalah gangguan jiwa di masyarakat tidak terjadi peningkatan. Hasil riset kesehatan dasar (2013) menunjukkan adanya penurunnan jumlah gangguan jiwa berat dan gangguan mental emosional secara nasional dibandingkan dengan hasil riset kesehatan dasar taahun 2007. Deteksi dini kesehatan jiwa perlu dilakukan untuk meningkatkan derajad kesehatan jiwa masyarakat agar individu yang sehat akan tetap sehat, individu yang berisiko tidak mengalami gangguan jiwa dan individu yang mengalami gangguan jiwa mendapatkan pelayanan yang tepat sehingga dapat mandiri dan produktif di masyarakat. Untuk meningkatkan derajad kesehatan jiwa masyarakat tersebut diperlukan peran serta pemerintah pusat, pemerintah daerah, tokoh masyarakat, kader, dan masyarakat melalui program Desa Siaga Sehat Jiwa.

Program Desa Siaga Sehat Jiwa merupakan salah satu program untuk mewujudkan desa yang penduduknya memiliki kesiapan sumber daya dan kemampuan untuk mengatasi masalah kesehatan jiwa secara mandiri. Tujuan umum Desa Siaga Sehat Jiwayaitu mewujudkan masyarakat desa yang sehat, peduli, dan tanggap terhadap permasalahan kesehatan jiwa di wilayahnya. Adapun tujuan khusus Desa Siaga Sehat Jiwa yaitu meningkatkan pengetahuan masyarakat tentang pentingnya kesehatan jiwa, meningkatkan kemampuan masyarakat menolong dirinya dalam bidang kesehatan jiwa, meningkatkan kesiapsiagaan masyarakat risiko dan bahaya kesehatan jiwa, dan meningkatkan dukungan dan peran aktif stakeholders serta meningkatkan masyarakat melaksanakan perilaku sehat jiwa.

Berdasarkan studi pendahuluan yang didapatkan dari bagian promosi kesehatan Puskesmas Kendal 2 didapatkan informasi bahwa desa yang ada dibawah binaan Puskesmas Kendal 2 selama ini belum pernah terpapar dengan program Desa Siaga Sehat Jiwa hingga jumlah gangguan jiwa. Berdasarkan latar belakang tersebut maka perlunya sosialisasi Desa Siaga Sehat Jiwa kepada kader dan perangkat desa Banyutowo dan selanjutnya dilakukan deteksi dini kesehatan jiwa untuk mengetahui gambaran kesehatan jiwa masyarakat desa Banyutowo.

\section{METODE}

Desain penelitian menggunakan metode penelitian kuantitatif deskriptif dengan jumlah populasi 400 keluarga. Pengambilan sampel penelitian ini menggunakan Purposive sampling, yaitu semua populasi yang ada yang memenuhi kriteria inklusi yang berjumlah 1217 orang. Penelitian dilakukan selama 6 (enam) bulan. Pemilihan tempat berdasarkan pada pengembangan wilayah binaan Departemen Keperawatan Jiwa STIKES Kendal fenomena 
yang ditemukan yaitu desa Banyutowo. Alat pengumpul data penelitian yang dilakukan menggunakan kuesioner yang berisi tentang karakteristik responden yang meliputi umur, pendidikan, status pernikahan dan pertanyaan terkait kesehatan jiwa masyarakat. Analisis data menggunakan analisa univariat dalam mendiskripsikan setiap variabel yang diteliti dalam penelitian, yaitu dengan melihat distribusi data pada data kategorik yang meliputi: usia

pendidikan, status pernikahan, dan gambaran kesehatan jiwa masyarakat.

\section{HASIL}

Adapun karakteristik responden berdasarkan usia disajikan pada tabel 1. Sedangkan karakteristik responden berdasarkan jenis kelamin, status pernikahan, pendidikan, dan pekerjaan disajikan pada tabel 2. Gambaran kesehatan jiwa responden disajikan pada tabel 3.

Tabel 1

Distribusi Karakteristik Responden ( $\mathrm{n}=1217)$

\begin{tabular}{lcc}
\hline \multicolumn{1}{c}{ Karakteristik Responden } & $\mathrm{f}$ & $\%$ \\
\hline Usia & 18 & 1,5 \\
Infant (0-18 bulan) & 8 & 0,7 \\
Todller ( $>18$ bulan -3 tahun) & 30 & 2,6 \\
Pra Sekolah ( $>3-6$ tahun) & 84 & 6,9 \\
Sekolah ( $>6-12$ tahun) & 86 & 7.3 \\
Remaja ( $>12-18$ tahun ) & 145 & 12,4 \\
Dewasa awal ( $>18-25$ tahun) & 674 & 57,6 \\
Dewasa ( $>25-60$ tahun) & 140 & 11 \\
Lansia ( $>60$ tahun & & \\
Jenis Kelamin & 618 & 50,8 \\
Laki-laki & 599 & 49,2 \\
Perempuan & & \\
\hline Status Pernikahan & 817 & 67,1 \\
Belum menikah & 314 & 25,8 \\
Menikah & 86 & 7,1 \\
Janda/ Duda & & \\
\hline Pendidikan & 160 & 13,1 \\
Tidak/Belum sekolah & 532 & 43,7 \\
SD & 209 & 17,2 \\
SLTP & 278 & 22,8 \\
SLTA & 38 & 3,1 \\
PT & &
\end{tabular}

Tabel 2.

Gambaran Kesehatan Jiwa Responden ( $\mathrm{n}=1217)$

\begin{tabular}{lcc}
\hline \multicolumn{1}{c}{ Kelompok } & $\mathrm{f}$ & $\%$ \\
\hline Sehat & 788 & 64,7 \\
\hline Resiko & 424 & 34,8 \\
\hline Gangguan & 5 & 0,4 \\
\hline
\end{tabular}

\section{PEMBAHASAN}

Hasil penelitian terkait deteksi dini kesehatan jiwa ini dapat membantu manyarakat memahami pentingnya kesehatan jiwa. Hal ini sesuai denagn hasil riset kesehatan dasar (2013) menunjukkan adanya penurunan jumlah gangguan jiwa berat dan gangguan mental emosional secara nasional dibandingkan dengan hasil riset kesehatan dasar tahun 2007.
Deteksi dini kesehatan jiwa perlu dilakukan untuk meningkatkan derajad kesehatan jiwa masyarakat agar individu yang sehat akan tetap sehat, individu yang berisiko tidak mengalami gangguan jiwa dan individu yang mengalami gangguan jiwa mendapatkan pelayanan yang tepat sehingga dapat mandiri dan produktif di masyarakat. Untuk meningkatkan derajad kesehatan jiwa masyarakat tersebut diperlukan 
peran serta pemerintah pusat, pemerintah daerah, tokoh masyarakat, kader, dan masyarakat melalui program Desa Siaga Sehat Jiwa.

Desa siaga sehat jiwa yang dibentuk di desa Banyutowo menunjukkan bahwa hasil deteksi dini yang peneliti kelompokkan menjadi 3 kelompok yaitu kelompok sehat, resiki, dan gangguan. Hasil penelitian menunjukkan bahwa terdapat 5 warga yang mengalami gangguan jiwa berat, meskipun mereka tidak dipasung namun tetap diperlukan upaya agar tetap produktif di masyarakat. Hasil penelitian ini membuktikan bahwa masih banyak masyarakat yang mengalami gangguan jiwa, bahkan akan sering bertambah apabila kelompok masyarakat yang sehat dan resiko tidak dilakukan tindakan pencegahan. Hal ini sesuai penjelasan WHO (2013) bahwa sehat adalah keadaan sejahtera secara fisik, mental dan sosial yang merupakan satu kesatuan.

Hasil penelitian menunjukkan bahwa mayoritas masyarakat desa Banyutowo dalam keadaan sehat. Hasil ini menunjukkan bahwa desa Banyutowo peduli akan kesehatan jiwa sehingga mereka yang berada dalam kelompok sehat, hendaknya mendapatkan tetap mendapatkan pelayanan kesehatan jiwa agar yang sehat tetap berada dalam keadaan sehat. Hasil penelitian ini didukung oleh undangundang R! Nomar 36 tahun 2009 tentang kesehatan mengamanatkan pembangunan kesehatan ditujukan untuk peningkatan kesadaran, kemauan, dan kemampuan hidup sehat bagi setiap orang agar terwujud derajad kesehatan yang setinggi-tingginya, sebagai investasi bagi pembangunan sumber daya manusia yang produktif secara sosial dan ekonomi.

Hasil penelitian menunjukkan bahwa 34,6\% masyarakat desa Banyutowo pada kelompok resiko, sehingga perlu upaya tindakan agar tidak masuk dalam kelompok gangguan. Beberapa masalah kesehatan jiwa di desa Banyutowo didominasi dengan adanya penyakit kronis yang diderita masyarakat seperti hipertensi, diabetes melitus, dan asam urat. Sedangkan masalah kesehatan jiwa remaja yang banyak terjadi yaitu terkait dengan ansietas dan stres dalam menghadapi gaya hidup remaja, kegagalan sosialisasi akibat penggunaan gadget, serta kanakalan remaja terkait mengkonsumsi minum-minuman keras dan rokok.

\section{SIMPULAN DAN SARAN Simpulan}

Mayoritas masyarakat desa Banyutowo, Kecamatan Kota Kendal, Kabupaten Kendal. peduli akan pentingnya kesehatan jiwa.

\section{Saran}

Perlu adanya peningkatan pengetahuan tentang kesehatan jiwa masyarakat secara berkala agar masyarakat desa juga dapat meningkatkan perilaku hidup bersih dan sehat.

\section{DAFTAR PUSTAKA}

Stuart, G.W. (2013). Principles and practice of psychiatric nursing (10thedition). St.Louis: Elsevier Mosby.

Anna, L.K. (2012). "Gangguan Jiwa masih diabaikan”. Kompas 11 Februari 2012.

Bahar, A., \& Syaify, A. (2013). Sehat \& Bugar selama berhaji. Depok: Penebar Swadaya.

Bappeda Kabupaten Kendal. (2012). Pengembangan sistem Informasi Profil daerah kabupaten Kendal tahun 2012. Kendal: Badan Perencanaan dan Pembangunan Daerah Kabupaten Kendal.

Kemenkes RI. (2013). Riset Kesehatan Dasar:RISKESDAS. Jakarta: Balitbang Kemenkes.

Kemenkes. (2013). Penyajian pokok-pokok hasil riset dasar kesehatan 2013. Jakarta: Badan penelitian dan pengembangan kesehatan Kementrian keseharan RI.

Kemenkes. (2013). Profil kesehatan provinsi Jawa tengah tahun 2012. Jakarta: Pusat data dan informasi Kementrian kesehatan RI

Thompson, M.S. (2007). Violence and the costs of caring for a family member with severe mental illness. Journal of Health and Social Behavior 48.3 : 318-333. 